\title{
Continuous enzyme-coupled assay of phosphate- or pyrophosphate-releasing enzymes
}

Antonio S. Guillén Suárez ${ }^{1,3}$, Alessandra Stefan ${ }^{1,2}$, Silvia Lemma ${ }^{1}$, Emanuele Conte ${ }^{1}$, and Alejandro Hochkoeppler ${ }^{1,2,3}$

${ }^{1}$ Department of Industrial Chemistry, University of Bologna, Bologna, Italy, ${ }^{2}$ CSGI, University of Firenze, Italy, and ${ }^{3}$ Department of Biochemistry and Molecular Biology I, Complutense University, Madrid, Spain

BioTechniques 53:99-103 (August 2012) doi 10.2144/000113905

Keywords: coupled assay; phosphate; pyrophosphate; DNA polymerases.

Supplementary material for this article is available at www.BioTechniques.com/article/113905

A coupled enzyme assay able to monitor the kinetics of reactions catalyzed by phosphate- or pyrophosphate-releasing enzymes is presented here. The assay is based on the concerted action of inorganic pyrophosphatase (PPase), purine nucleoside phosphorylase (PNPase), and xanthine oxidase (XOD). In the presence of phosphate, PNPase catalyzes the phosphorolysis of inosine, generating hypoxanthine, which is oxidized to uric acid by XOD. The uric acid accordingly formed can be spectrophotometrically monitored at $293 \mathrm{~nm}$, taking advantage of a molar extinction coefficient which is independent of $\mathrm{pH}$ between 6 and 9. The coupled assay was tested using DNA polymerases as a model system. The activity of Klenow enzyme was quantitatively determined, and it was found in agreement with the corresponding activity determined by traditional methods. Moreover, the continuous coupled assay was used to determine $K_{\mathrm{m}}$ and $V_{\max }$ of Klenow enzyme, yielding values in good agreement with previous observations. Finally, the coupled assay was also used to determine the activity of partially purified DNA polymerases, revealing its potential use to monitor purification of phosphate- or pyrophosphate-releasing enzymes.

The detection of inorganic phosphates represents an analytical challenge in the environmental, agricultural, and industrial areas. Accordingly, the relevance of phosphates as analytical targets has prompted the development of chemical methods for their determination. In addition, chemosensors for phosphates were recently designed, synthesized, and tested $(1,2)$. Using traditional or chemosensor-assisted chemical methods, phosphates can be detected using sensitive, simple, and cost-effective procedures, some of which can also be miniaturized (3) and fully automated (4). Nevertheless, these procedures are discontinuous, rendering rather cumbersome the kinetic evaluation of reactions involving phosphates.

Over the years, different enzymatic methods have been proposed for the detection of inorganic phosphates or pyrophosphates. By coupling the reactions catalyzed by purine nucleoside phosphorylase (PNPase; EC 2.4.2.1) and xanthine oxidase (XOD; EC 1.17.3.2, formerly 1.2.3.2), de Groot et al. were able to quantitatively assay inorganic and organic phosphate (5). Including inorganic pyrophosphatase (PPase; EC 3.6.1.1) in their assay, de Groot et al. were also able to quantitate inorganic pyrophosphate (5). This method relies on the following steps (Supplementary Figure S1): (i) pyrophosphate is converted to phosphate by PPase; (ii) PNPase catalyzes the phosphorolysis of inosine to hypoxanthine and ribose-1-phosphate; and (iii) XOD oxidizes hypoxanthine to uric acid, the absorbance of which can be spectrophotometrically monitored (e.g., at 293 $\mathrm{nm})$. This assay performed well to analyze total phosphate or pyrophosphate concentrations, i.e., by determining the absorbance increase at reaction completion. Unfortunately, de Groot et al. did not investigate in detail the potential use of their method to study the kinetics of reactions catalyzed by enzymes releasing phosphate or pyrophosphate (5). Moreover, they used PNPase $(500 \mathrm{mU} / \mathrm{mL})$ in excess over XOD $(50 \mathrm{mU} / \mathrm{mL})$, while the opposite should be for this enzyme-coupled assay $(6,7)$. Similarly, the optimal amount of auxiliary enzymes was not determined for the coupled assay of pyrophosphate relying on sulfate adenyltransferase (8).

A simple kinetic assay for phosphatereleasing enzymes was proposed by Webb
(9). In this case, PNPase was used to convert phosphate and 2-amino-6-mercapto-7methylpurine ribonucleoside (e.g., methylthioguanosine, MESG) into ribose-1-phosphate and 2-amino-6-mercapto-7-methylpurine. At pH 7.6 and $360 \mathrm{~nm}$, the difference in absorbance between MESG and the corresponding base generated by PNPase yields a $\Delta \varepsilon$ equal to $11,000 \mathrm{M}^{-1} \mathrm{~cm}^{-1}$ (9). Accordingly, the assay proposed by Webb eliminates the need to couple PNPase and XOD reactions. However, this method features the disadvantage that, at $\mathrm{pH}$ values below 7.6, the $\Delta \varepsilon$ between MESG and the reaction product strongly decreases (9).

More recently, Tagiri-Endo reported on the use of hypoxanthine-guanine phosphoribosyl transferase (HGPRT; EC 2.4.2.8) to detect the pyrophosphate released during the action of DNA polymerases (10). However, this assay was specifically designed to estimate the amount of DNA amplified by PCR, and no attempts were made to evaluate the kinetics of reactions catalyzed by DNA polymerases.

A continuous enzyme-coupled assay of phosphate- or pyrophosphate-releasing enzymes (PREs) is presented here. In 
particular, the PPase-PNPase-XOD (PPX) system was investigated in detail to: $(i)$ identify the concentration of each auxiliary enzyme necessary to correctly detect the kinetics of reactions catalyzed by PREs; (ii) define the $\mathrm{pH}$ interval where the activity of PREs can be determined; (iii) compare the PPX assay with a well known reference method (11). Finally, DNA polymerases were chosen as a model to test the PPX system.

\section{Materials and methods}

\section{Materials}

Escherichia coli PPase (recombinant), bacterial PNPase, bacterial xXOD, type $\mathrm{XV}$ activated calf thymus DNA (12), and analytical grade reagents were from SigmaAldrich. The Klenow fragment of E. coli DNA polymerase I was from New England Biolabs (Ipswich, MA, USA). Crude $E$. coli DNA polymerase III holoenzyme was prepared as previously described (13).

\section{Determination of phosphate with Malachite green}

The procedure described by Baykov et al. (3) was used as a reference method to detect orthophosphate in aqueous samples. Briefly, a $5 x$ assay mixture was obtained by mixing $10 \mathrm{~mL}$ of Malachite green solution ( $1.2 \mathrm{~g}$ in $1 \mathrm{~L}$ of $3 \mathrm{M}$ sulphuric acid) with $2.5 \mathrm{~mL}$ of a freshly-prepared ammonium molybdate solution $\left(7.5 \%\right.$, w/v in $\mathrm{H}_{2} \mathrm{O}$ ) and $0.2 \mathrm{~mL}$ of $10 \%(\mathrm{v} / \mathrm{v})$ Tween 20 . To detect orthophosphate, $40 \mu \mathrm{L}$ of the $5 \times$ assay mixture were added to $160 \mu \mathrm{L}$ of each sample; upon incubation at $37^{\circ} \mathrm{C}$ for 30 min, the absorbance at $600 \mathrm{~nm}$ was determined using a Bio-Rad (Hercules, CA, USA) 550 microplate reader. To quantitate orthophosphate, an appropriate calibration curve (ranging from 0 to $12.5 \mu \mathrm{M}$ ) was used. The activity of DNA polymerases was determined in the presence of $100 \mathrm{mM}$ Tris- $\mathrm{HCl} \mathrm{pH} \mathrm{7.8,} 65 \mu \mathrm{g} / \mathrm{mL}$ of activated DNA, $10 \mathrm{mM} \mathrm{MgCl}, 200 \mu \mathrm{M}$ dNTPs, 60 $\mathrm{mU}$ of PPase. The reactions were stopped by the addition of the Malachite green assay mixture. Controls were carried out in the absence of $\mathrm{MgCl}_{2}$ and in the presence of 10 mM EDTA.

\section{Enzyme assays}

PPase, PNPase, and XOD units (U) are defined as the amount of enzyme able to produce per min, at $25^{\circ} \mathrm{C}, 1 \mu \mathrm{mol}$ of product at $\mathrm{pH} 9.0,7.4$, and 7.5 , respectively. The activity of DNA polymerases was assayed in the presence of activated calf thymus DNA $(65 \mu \mathrm{g} / \mathrm{mL})$ or in the presence of 2.5 $\mu \mathrm{M}$ poly-dA: oligo-dT (60-mer and 20 -mer, respectively). The assay mixture contained $100 \mathrm{mM}$ Tris- $\mathrm{HCl} \mathrm{pH} 7.8,5$ mM MgCl ,


Figure 1. Initial velocities of reactions catalyzed by XOD (A), PNPase (B), and PPase (C), as a function of substrate (A, B) or enzyme (C) concentration. (A) Initial velocities of hypoxanthine oxidation by $\mathrm{XOD}$ as a function of substrate concentration. The assays were carried out at pH 7.8 (100 mM Tris$\mathrm{HCl}$ ) in the presence of $25 \mathrm{mU} / \mathrm{mL}$ of enzyme. (B) initial velocities, at pH 7.8, of inosine phosphorolysis by PNPase as a function of phosphate concentration. The assay mixtures contained $5 \mathrm{mM}$ $\mathrm{MgCl}_{2}, 0.25 \mathrm{mM}$ inosine, $500 \mathrm{mU} / \mathrm{mL}$ of XOD and $10 \mathrm{mU} / \mathrm{mL}$ of PNPase. (C) Initial velocities, at $\mathrm{pH}$ 7.8 , of pyrophosphate hydrolysis by PPase in the presence of 50 and $500 \mathrm{mU} / \mathrm{mL}$ of PNPase and $\mathrm{XOD}$, respectively. Other conditions as in Figure $1 \mathrm{~B}$, except for the absence of phosphate and the presence of $5 \mathrm{mM}$ pyrophosphate.

$0.25 \mathrm{mM}$ inosine, $0.1 \mathrm{mM}$ dNTPs (or 0.1 $\mathrm{mM}$ dTTP), and 5,50 , and $500 \mathrm{mU} / \mathrm{mL}$ of PPase, PNPase, and XOD, respectively. The reactions were started by addition of

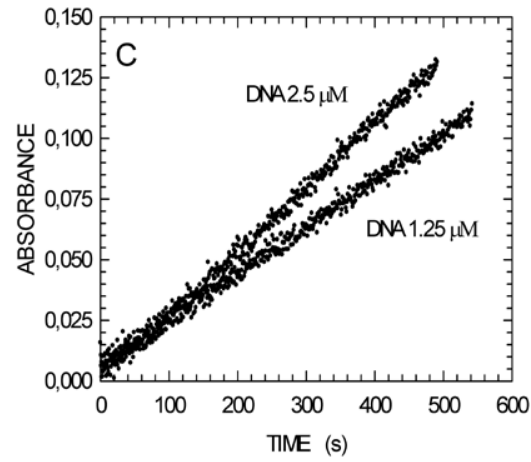

Figure 2. Kinetics of DNA replication catalyzed by Klenow enzyme. (A) Time course of the absorbance at $293 \mathrm{~nm}$ of a reaction mixture containing $100 \mathrm{mM}$ Tris- $\mathrm{HCl}(\mathrm{pH} 7.8)$, Klenow polymerase, $2.5 \mu \mathrm{M}$ oligo-dT, $5 \mathrm{mM} \mathrm{MgCl}, 0.25$ $\mathrm{mM}$ inosine, 5, 50 and $500 \mathrm{mU} / \mathrm{mL}$ of PPase, PNPase, and XOD, respectively. (B) Time course of the absorbance at $293 \mathrm{~nm}$ of the assay mixture of Figure $2 \mathrm{~A}$, supplemented with $2.5 \mu \mathrm{M}$ poly-dA. (C) Initial velocites of Klenow-catalyzed DNA replication in the presence of 1.25 or 2.5 $\mu \mathrm{M}$ poly-dA:oligo-dT and $100 \mu \mathrm{m}$ dTTP. Other conditions as in Figure 2B.

dTTP, and monitored at $293 \mathrm{~nm}$ using a PerkinElmer (Waltham, MA, USA) $\lambda 19$ spectrophotometer. At this wavelength, the $\varepsilon$ of uric acid was assumed equal to $12.6 \times$ $10^{3} \mathrm{M}^{-1} \mathrm{~cm}^{-1}$ (14).

DNA polymerization reactions were also assayed in the presence of $0.5 \mathrm{mM}$ 2-(4-Iodophenyl)-3-(4-nitrophenyl)-5phenyl-2H-tetrazolium chloride (INT), and monitored at $460 \mathrm{~nm}$. At this wavelength, the $\varepsilon$ of INT-formazan was assumed equal to $12.5 \times 10^{3} \mathrm{M}^{-1} \mathrm{~cm}^{-1}(15)$.

\section{Microplate assays}

The E. coli DNA polymerase III catalytic core (comprising the $\alpha, \varepsilon$, and $\theta$ subunits) was overexpressed in E. coli TOP10 as previously described (16). Upon overexpression, soluble proteins were extracted (using 50 $\mathrm{mM}$ Tris- $\mathrm{HCl} \mathrm{pH} 8,50 \mathrm{mM} \mathrm{NaCl}, 1 \mathrm{mM}$ EDTA) and loaded onto a Q-Sepharose FF column. A linear $\mathrm{NaCl}$ gradient (from 50 to $600 \mathrm{mM}$ ) was then applied to the column, and 70 fractions were collected. 

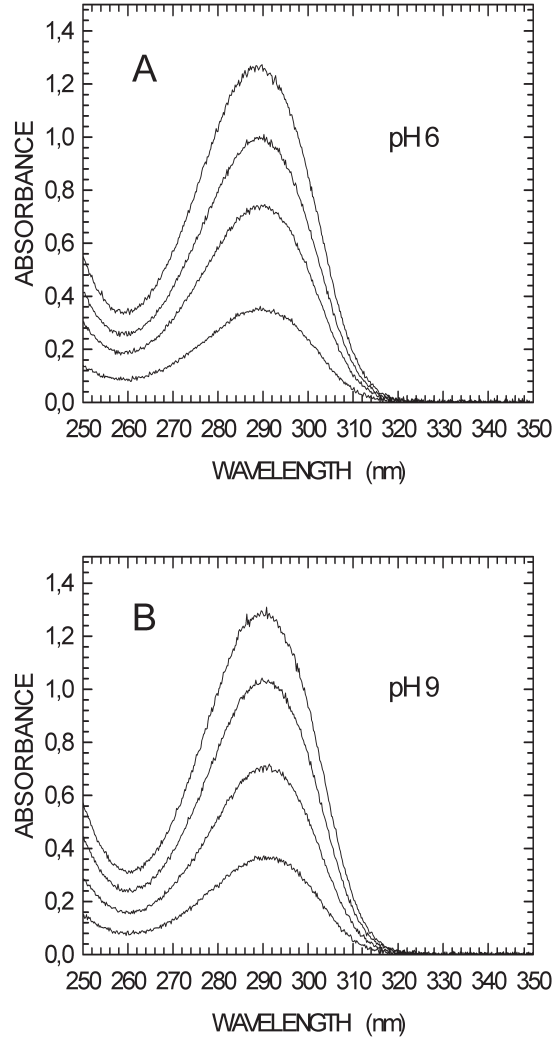

Figure 3. Absorption spectra of $25,50,75$, and $100 \mu \mathrm{M}$ uric acid at $\mathrm{pH} 6(\mathrm{~A})$ and 9 (B). Buffering was provided, at both $\mathrm{pH}$ values, by the universal Mes-Tris buffer.

The exonuclease activity of the $\varepsilon$ subunit was assayed with thymidine 5 '-monophosphate $p$-nitrophenyl ester, as described by Hamdan et al. (17). The polymerase activity of the $\alpha$ subunit was determined using our coupled assay in the presence of $65 \mu \mathrm{g} / \mathrm{mL}$ of activated calf thymus DNA and $0.5 \mathrm{mM}$ INT. Both exonuclease and polymerase activities were assayed (at 420 and $450 \mathrm{~nm}$, respectively) using microplates and a Bio-Rad (Hercules, CA, USA) 550 microplate reader.

\section{Results and discussion}

As a first step, we decided to evaluate the presence of phosphates in the reagents that we used to determine DNA polymerase activity. To this aim, each reagent was analyzed by the conventional Malachite green method (3), and the concentration of phosphates was quantitated using a calibration curve, ranging from 0 to $12.5 \mu \mathrm{M}(\mathrm{Abs}=0.019+$ $0.046 \times\left[\mathrm{P}_{i}\right]$, Supplementary Figure S2A). No significant contamination was detected in Tris- $\mathrm{HCl}, \mathrm{MgCl}_{2}$, and calf thymus activated DNA (Supplementary Figure S2B). On the contrary, significant levels of phosphates were determined in dNTPs (purchased from two different suppliers),

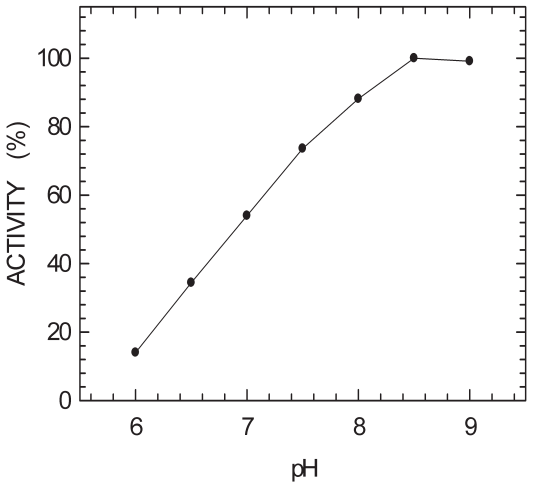

Figure 4. Pyrophosphatase (PPase) activity as a function of $\mathrm{pH}$, in the presence of the universal Mes-Tris buffer and $10 \mathrm{mU} / \mathrm{mL}$ of PPase. Other conditions as in Figure 1C.

and in both DNA polymerases tested, i.e., E. coli DNA polymerase III (DNA Pol-III) and Klenow fragment of DNA polymerase I (Supplementary Figure S2C). Therefore, to avoid contamination by phosphates, we extensively dialyzed the two polymerases against Tris- $\mathrm{HCl}$, and we used dNTPs from New England Biolabs. The concentration of phosphates in these dNTPs was indeed found to be very low ( $\leq 1 \%$, data not shown). To avoid contamination by phosphates, it is however important to prepare frozen aliquots freezing and thawing of these solutions, a significant increase in the concentration of phosphates was observed (data not shown).

To determine the appropriate amount of each enzyme to be used in the coupled assay, we first determined the relevant catalytic constants of XOD and PNPase at pH 7.8 $(100 \mathrm{mM}$ Tris-HCl). First, we assayed XOD activity, as a function of hypoxanthine concentration, in the presence of 25 $\mathrm{mU} / \mathrm{mL}$ of enzyme. Under these conditions, we estimated $K$ and $V$ equal to $52.7 \pm 5.7 \mu \mathrm{M}$ and $33.5 \pm 1.5 \mathrm{nM} / \mathrm{s}$, respectively (Figure 1A). Next, we assayed PNPase activity, as a function of phosphate concentration, in the presence of $5 \mathrm{mM} \mathrm{MgCl}_{2}$, $0.25 \mathrm{mM}$ inosine, $500 \mathrm{mU} / \mathrm{mL}$ of XOD and $10 \mathrm{mU} / \mathrm{mL}$ of PNPase. Under these condiof dNTP stock solutions. Upon repeated tions, $K_{\mathrm{m}}$ and $V_{\max }$ were estimated equal to $170 \pm 8 \mu \mathrm{M}$ and $285 \pm 3 \mathrm{nM} / \mathrm{s}$, respectively (Figure 1B). According to Lee et al. (18), the PNPase supplied by Sigma-Aldrich is isolated from Cellulomonas sp., and features a $K$ for phosphate equal to $167 \pm 22 \mu \mathrm{M}$ at $\mathrm{pH}$ 7.6. Therefore, our use of XOD to assay PNPase activity appears quantitatively reliable, and suggests the optimal concentration of these two enzymes when performing the PPX assay.

According to McClure (6), when two auxiliary enzymes are used in a coupled assay, the lag time necessary to reach steadystate conditions approaches a minimum when the first-order rate constant $\left(V_{\max }\right)$ $K_{\mathrm{m}}$ ) of the secondary auxiliary enzyme is about 4-fold the corresponding constant of the primary auxiliary enzyme. This means, taking into account the constants reported here $\left(V_{\mathrm{max}} / K_{\mathrm{m}}\right.$ equal to $6.4 \times 10^{-4}$ and $4.2 \times 10^{-3}$ for XOD and PNPase at 25 $\mathrm{mU} / \mathrm{mL}$, respectively), that a 25 -fold excess of XOD over PNPase should be used to minimize the lag time. Alternatively, to save auxiliary enzymes, McClure proposed the use of amounts giving equal first-order rate constants (6). In our case, this translates into using XOD 6-7 times in excess over PNPase. Similar considerations arise when the theory of Storer and Cornish-Bowden (7) is applied. Indeed, an excess of about 10-fold of XOD over PNPase should be used to attain maximal velocities for both enzymecatalyzed reactions in approximately equal times. Therefore, we decided to test PPase activity in the presence of 50 and $500 \mathrm{mU} /$ $\mathrm{mL}$ of PNPase and XOD, respectively. As Figure 1C shows, a linear dependence of pyrophosphatase activity as a function of PPase concentration was observed in the range $2-20 \mathrm{mU} / \mathrm{mL}$ of PPase. According to this observation, we propose that, to detect a pyrophosphate-liberating enzyme (such as a DNA polymerase), 2-10, 50, and 500 $\mathrm{mU} / \mathrm{mL}$ of PPase, PNPase, and XOD can be conveniently used, respectively.

As a model system to test our enzyme coupled assay, we selected the Klenow fragment of $E$. coli DNA polymerase I.

\section{Bone Osteoclastic Resorption Activity by SUPERNATE FLUORESCENCE...easy!}

Another unique biotool...only from Cosmo Bio

COSMO BIO CO., LTD. Inspiration for Life Science
USA

\& Canada

All Other

Countries www.cosmobiousa.com 760-431-4600

info@cosmobiousa.com

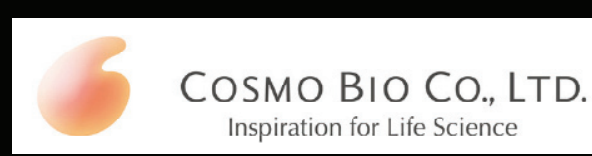

www.cosmobio.com +81-3-5632-9617

export@cosmobio.co.jp 
According to the reaction velocities observed with different concentrations of coupling enzymes (see above) we decided to use 5 , 50 , and $500 \mathrm{mU}$ of PPase, PNPase, and $\mathrm{XOD}$, respectively. Furthermore, in order to perform a set of appropriate controls, poly-dA:oligo-dT was chosen as substrate. As a first test, we incubated Klenow enzyme with $2.5 \mu \mathrm{M}$ oligo-dT, in the absence of both poly-dA and dTTP. No appreciable activity was detected under these conditions (Figure 2A). Moreover, when $2.5 \mu \mathrm{M}$ poly-dA was added to the reaction mixture (in the presence of $2.5 \mu \mathrm{M}$ oligo-dT), no significant activity was detected in the absence of dTTP (Figure 2B). On the contrary, when $2.5 \mu \mathrm{M}$ poly-dA:oligo-dT and $100 \mu \mathrm{M}$ dTTP were present, a linear increase in absorbance at $293 \mathrm{~nm}$ was readily observed (Figure 2C). Under the same conditions, the polymerase activity detected in the presence of $1.25 \mu \mathrm{M}$ polydA:oligo-dT was slightly lower when compared with the activity observed with 2.5 $\mu \mathrm{M}$ DNA (Figure 2C), indicating that the kinetics is zero-order. To further inspect the kinetics of DNA elongation catalyzed by Klenow, we assayed polymerase activity as a function of poly-dA:oligo-dT concentration (at $100 \mu \mathrm{M}$ dTTP). Under these conditions, $K_{\mathrm{m}}$ and $V_{\max }$ were calculated equal to $12.4 \mathrm{nM}$ and $6.1 \mathrm{nM} / \mathrm{s}$, respectively (Supplementary Figure S3). Our estimation of $K$ is about 2-fold higher than previously published values $\left(K_{\mathrm{D}}, 5-6 \mathrm{nM}\right)$, referring to synthetic oligonucleotides (19-21). It is however worthy to note that we used a substrate different from previously used DNAs (19-21). Unfortunately, we were unable to determine the concentration of Klenow enzyme used in our assays. The protein concentration of the dialyzed stock enzyme solution was indeed below the sensitivity limit of the micro-Bradford method $(1 \mu \mathrm{g} / \mathrm{mL})$. Taking into account the volume of stock enzyme solution used per assay, we estimate that the final concentration of Klenow polymerase was below $2.4 \mathrm{nM}$ in each assay. This, in turn, means that the magnitude of $\mathrm{k}_{\mathrm{cat}}$ is $\geq 2.5 \mathrm{~s}^{-1}$.

To compare our enzyme coupled assay with a reference method, we used the conventional Malachite green procedure to detect phosphates. In particular, the activity of the Klenow enzyme and of a partially-purified E. coli DNA Pol-III (13) were tested using both the coupled enzyme assay and the Malachite green method. Moreover, we wanted to evaluate if the two methods, when applied to Klenow enzyme, yielded activity values compatible with those indicated by the manufacturer (New England Biolabs). To this aim, the polymerase activity was assayed under the conditions indicated by New England Biolabs, i.e., at $37^{\circ} \mathrm{C}$, using activated calf thymus DNA as substrate, and incubating the reaction mixture for 30 min. When 0.1 units of Klenow were used, we detected the release of $0.54 \pm 0.07 \mathrm{nmol}$ of pyrophosphate in $30 \mathrm{~min}$ with the Malachite green assay. When the enzyme coupled assay was performed under the same conditions, 0.1 units of Klenow enzyme produced 0.50 $\pm 0.01 \mathrm{nmol}$ of pyrophosphate in $30 \mathrm{~min}$. This value indicates that the coupled assay reliably estimates DNA polymerase activity. In addition, the values of activity obtained by the conventional Malachite green method and by the coupled assay are in reasonable agreement with the activity indicated by the manufacturer, i.e., 10 nmol of pyrophosphate released by 1 unit of Klenow in 30 min at $37^{\circ} \mathrm{C}$. It should be noted that our enzyme coupled assay can be performed using electron acceptors other than oxygen, e.g., 2-(4-iodophenyl)-3-(4-nitrophenyl)-5phenyl-2H-tetrazolium chloride (INT). In this case the assay would rely on the detection of INT-formazan, which can be conveniently monitored at 458 (22) or $460 \mathrm{~nm}$ (15). Therefore, we determined the activity of Klenow enzyme using our coupled assay in the presence of activated calf thymus DNA as substrate and $0.5 \mathrm{mM}$ INT as electron acceptor. Under these conditions, 0.1 units of enzyme yielded $0.29 \pm 0.01 \mathrm{nmol}$ of pyrophosphate in $30 \mathrm{~min}$ (Supplementary Figure S4). This value is significantly lower than those obtained with the Malachite Green method and with our coupled assay performed in the presence of oxygen as the terminal electron acceptor (see above). We propose that this discrepancy is linked to the $\varepsilon$ of INT-formazan (we used $12.5 \times$ $10^{3} \mathrm{M}^{-1} \mathrm{~cm}^{-1}$ ), which has been difficult to determine (15).

It is important to note that INT-formazan can be detected at wavelengths compatible with assays dealing with partially purified enzyme preparations. To test this point, we overexpressed $E$. coli DNA polymerase III catalytic core, containing the $\alpha$ (polymerase), $\varepsilon$ ( $3^{\prime}-5^{\prime}$ exonuclease), and $\theta$ subunits. In particular, soluble proteins were extracted from $E$. coli TOP10 subjected to overexpression of the core, and the extract accordingly obtained was loaded onto a Q-Sepharose FF column and eluted with a linear $\mathrm{NaCl}$ gradient. An aliquot of each collected fraction was then subjected to our coupled assay performed in microplates in the presence of $0.5 \mathrm{mM}$ INT (see Materials and methods). As a reference assay, we determined in parallel the exonuclease activity of $\varepsilon$, under the conditions reported by Hamdan et al. (17). The polymerase and the exonuclease activity peaks were found to overlap satisfactorily (Supplementary Figure S5), indicating that our INT-based microplate assay of polymerase activity is reliable, and can be conveniently used to monitor purification of phosphate- or pyrophosphatereleasing enzymes.

The Malachite green method was also used to test the activity, in the presence of activated calf thymus DNA, of a partially purified preparation of E. coli DNA pol-III (13). After $30 \mathrm{~min}$ of incubation at $37^{\circ} \mathrm{C}$, we estimated the release of $1 \pm 0.15 \mathrm{nmol}$ of pyrophosphate. When the enzyme-coupled assay was performed under the same conditions (in the presence of oxygen as electron acceptor), we observed polymerase activity equal to $0.7 \pm 0.04 \mathrm{nmol}$ of pyrophosphate generated in $30 \mathrm{~min}$. Taking into account the comparisons presented here, we propose the PPX coupled assay as a reliable approach to continuously determine the activity of DNA polymerases.

To evaluate the potential use of our enzyme coupled assay over a wide $\mathrm{pH}$ interval, we determined the molar extinction coefficient of uric acid at $\mathrm{pH} 6$ and 9. To this aim, we used the previously described Mes-Tris universal buffer (23), which is known to span a wide $\mathrm{pH}$ interval at constant ionic strength (23). As Figures 3A-3B show, at both $\mathrm{pH}$ values uric acid features maximal absorbance at 290 $\mathrm{nm}$. This observation was confirmed, for both $\mathrm{pH}$ values, by inspection of the first-derivative spectra (data not shown). Our estimate of $\lambda$ significantly differs from previously reported values, indicating $293 \mathrm{~nm}$ as the wavelength of maximal molar absorbance by uric acid (14). However, it should be mentioned that Smith observed a significant shift (from 292 to 295 $\mathrm{nm})$ of $\lambda_{\text {max }}$, when comparing the spectra of uric acid in phosphate and carbonate buffers (24). Moreover, a concentration dependence shift of the specific molar absorbance of uric acid was reported (25). We therefore propose $290 \mathrm{~nm}$ as the $\lambda$ for uric acid at $\mathrm{pH} 6$ and 9 , in Mes-Tris buffer. In addition, according to the data reported in Figures 3A-3B, we propose $12 \times 10^{3}$ and $12.4 \times 10^{3} \mathrm{M}^{-1} \mathrm{~cm}^{-1}$ as the $\varepsilon$ of uric acid at $290 \mathrm{~nm}$, at pH 6 and 9 , respectively.

The activities of Cellulomonas sp. PNPase (18) and bacterial XOD feature $\mathrm{pH}$ optimum at 7.5-8.0. On the contrary, the $\mathrm{pH}$ optimum of $E$. coli PPase is equal to 8.5-9.0 (26). Therefore, to further test the $\mathrm{pH}$-dependence of our enzyme-coupled assay, we determined PPase activity as a function of $\mathrm{pH}$, using the Mes-Tris universal buffer. As Figure 4 shows, PPase activity features a maximum at $\mathrm{pH}$ 8.5-9.0, in agreement with previous observations reported by Josse (26). In addition, at $\mathrm{pH} 6$ the activity drops to $15 \%$ of the maximum (Figure 4). It is interesting to note that Josse, using maleate buffer, reported at $\mathrm{pH} 6$ a relative activity equal to less than $10 \%$ of the maximum (26). The difference between these and our observations could be because of our use of a universal buffer, which 
avoids potentially inhibitory or stimulatory effects exerted by the different buffers used in activity assays performed as a function of $\mathrm{pH}$. Therefore, we propose that our enzyme coupled assay could be used at $\mathrm{pH} 6-7$ upon increasing the concentration of PPase, e.g. to $10-50 \mathrm{mU} / \mathrm{mL}$ instead of $2-10 \mathrm{mU} / \mathrm{mL}$, as optimal for assays at $\mathrm{pH} 7-8$.

According to the observations reported here, the PPX enzyme coupled assay was shown to represent a robust and sensitive method to perform activity assays of phosphate- or pyrophosphate-releasing enzymes. Using this coupled assay, enzyme activities can indeed be determined continuously, quantitatively, and over a wide $\mathrm{pH}$ range. Moreover, the assay can be performed in microplates to determine the activity of partially purified enzyme preparations.

\section{Competing interests}

The authors declare no competing interests.

\section{References}

1.Martínez-Máñez, R. and F. Sancenón. 2003. Fluorogenic and chromogenic chemosensors and reagents for anions. Chem. Rev. 103:4419-4476.

2. Kim, S.K., D.H. Lee, J. Hong, and J. Yoon. 2009. Chemosensors for pyrophosphate. Acc. Chem. Res. 42:23-31.

3. Baykov, A.A., O.A. Evtushenko, and S.M. Avaeva. 1988. A malachite green procedure for orthophosphate determination and its use in alkaline phosphatase-based enzyme immunoassay. Anal. Biochem. 171:266-270.

4. Pegan, S.D., Y. Tian, V.Sershon, and A.D. Mesecar. 2010. A universal, fully automated high throughput screening assay for pyrophosphate and phosphate release from enzymatic reactions. Comb. Chem. High Throughput Screen. 13:27-38.

5. de Groot, H., H. de Groot, and T. Noll. 1985. Enzymic determination of inorganic phosphates, organic phosphates and phosphate-liberating enzymes by use of nucleoside phosphorylasexanthine oxidase (dehydrogenase)-coupled reactions. Biochem. J. 230:255-260.

6. McClure, W.R. 1969. Kinetic analysis of coupled enzyme assays. Biochemistry 8:2782-2786.

7. Storer, A.C. and A. Cornish-Bowden. 1974. The kinetics of coupled enzyme reactions. Applications to the assay of glucokinase, with glucose 6-phosphate dehydrogenase as coupling enzyme. Biochem. J. 141:205-209.

8. Dancer, J.E. and T. ap Rees. 1989. Phosphoribosyl pyrophosphate and the measurement on inorganic pyrophosphate in plant tissues. Planta 177:261264.

9. Webb, M.R. 1992. A continuous spectrophotometric assay for inorganic phosphate and for measuring phosphate release kinetics in biological systems. Proc. Natl. Acad. Sci. USA 89:4884-4887.

10. Tagiri-Endo, M. 2003. A colorimetric assay for inorganic pyrophosphate that is also useful for measuring product accumulation in polymerase chain reactions. Anal. Biochem. 315:170-174.

11. Fiske, C.H. and Y. Subbarow. 1925. The colorimetric determination of phosphorus. J. Biol. Chem. 66:375-400.
12. Aposhian, H.V. and A. Kornberg. 1962. Enzymatic synthesis of deoxyribonucleic acid: IX. The polymerase formed after T2 bacteriophage infection of Escherichia coli: a new enzyme. J. Biol. Chem. 237:519-525.

13. Bressanin, D., A.Stefan, F. Dal Piaz, S. Cianchetta, L. Reggiani, and A. Hochkoeppler. 2009. Proteolysis of the proofreading subunit controls the assembly of Escherichia coli DNA polymerase III catalytic core. Biochim. Biophys. Acta 1794:16061615.

14. Scheibe, P., E. Bernt, and H.U. Bergmeyer. 1974. Uric acid: UV-assay with uricase, p. 1999-2005. In H.U. Bergmeyer (Ed.), Methoden der Enzymatischen Analyse, Verlag Chemie, Weinheim.

15. Sowerby, J.M. and J.H. Ottaway. 1966 . The enzymic estimation of glutamate and glutamine. Biochem. J. 99:246-252.

16. Conte, E., G. Landolfi, G. Vincelli, A.Stefan, and A. Hochkoeppler. 2011.pGOODs: new plasmids for the co-expression of proteins in Escherichia coli. Biotechnol. Lett. 33:1815-1821.

17. Hamdan, S., E.M. Bulloch, P.R. Thompson, J.L. Beck, J.Y. Yang, J.A. Crowther, P.E. Lilley, P.D. Carr, et al. 2002. Hydrolysis of the 5'-p-nitrophenyl ester of TMP by the proofreading exonuclease $(\varepsilon)$ subunit of Escherichia coli DNA polymerase III. Biochemistry 41:5266-5275.

18. Lee, J., S. Filosa, J. Bonvin, S. Guyon, R.A. Aponte, and J.L. Turnbull. 2001. Expression, purification, and characterization of recombinant purine nucleoside phosphorylase from Escherichia coli. Protein Expr. Purif. 22:180-188.

19. Kuchta, R.D., V. Mizrahi, P.A. Benkovic, K.A. Johnson, and S.J. Benkovic. 1987. Kinetic mechanism of DNA polymerase I (Klenow). Biochemistry 26:8410-8417.

20. Polesky, A.H., T.A. Steitz, N.D. Grindley, and C.M.Joyce. 1990. Identification of residues critical for the polymerase activity of the Klenow fragment of DNA polymerase I from Escherichia coli. J. Biol. Chem. 265:14579-14591.

21. McClure, W.R. and T.M. Jovin. 1975. The steady state kinetic parameters and non-processivity of Escherichia coli deoxyribonucleic acid polymerase I. J. Biol. Chem. 250:4073-4080.

22. Green, J.D. and H.T. Narahara. 1980. Assay of succinate dehydrogenase activity by the tetrazolium method: evaluation of an improved technique in skeletal muscle fractions. J. Histochem. Cytochem. 28:408-412.

23. Ellis, K.J. and J.F. Morrison. 1982. Buffers of constant ionic strength for studying $\mathrm{pH}$-dependent processes. Methods Enzymol. 87:405-426.

24. Smith, F.C. 1928. The ultra-violet absorption spectra of uric acid and of the ultra-filtrate of serum. Biochem. J. 22:1499-1503.

25. Vasilevskii, A.M., G.A. Konoplev, and N.V. Kornilov. 2001. Study of the absorption spectra of albumin and uric acid in the UV region. J. Opt. Technol. 68:928-930.

26. Josse, J. 1966. Constitutive inorganic pyrophosphatase of Escherichia coli. I. Purification and catalytic properties. J. Biol. Chem. 241:19381947.

Received 16 April 2012; accepted 28 June 2012.

Addresscorrespondence to Alejandro Hochkoeppler, Department of Industrial Chemistry, University of Bologna, Viale Risorgimento 4, 40136 Bologna, Italy.Email: a.hochkoeppler@unibo.it

To purchase reprints of this article, contact: biotechniques@fosterprinting.com


\section{One Click. One Source.}

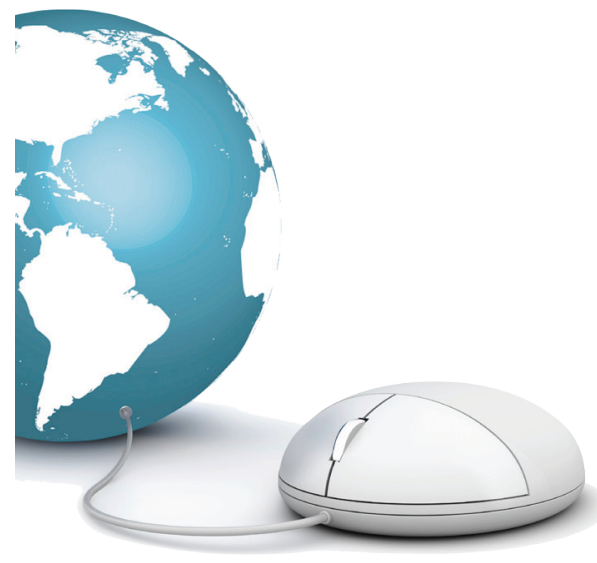

Richer. Easier. Engaging.

\section{the NEW mpbio.com}

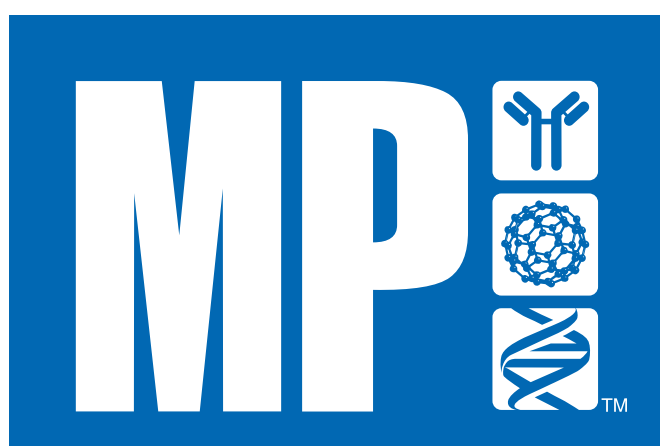

